\title{
Genotypic Variations in Plant Growth and Nutritional Elements of Perennial Ryegrass Accessions under Salinity Stress
}

\author{
Xin Song \\ State Key Laboratory of Grassland Agro-ecosystems, College of Pastoral Agriculture Science and \\ Technology, Lanzhou University, Lanzhou, 730000, People's Republic of China; and Department of \\ Agronomy, Purdue University, West Lafayette, IN 47907 \\ Suo-min Wang \\ State Key Laboratory of Grassland Agro-ecosystems, College of Pastoral Agriculture Science and \\ Technology, Lanzhou University, Lanzhou, 730000, People's Republic of China \\ Yiwei Jiang ${ }^{1}$ \\ Department of Agronomy, Purdue University, West Lafayette, IN 47907
}

Additional INDEX words. ion element, Lolium perenne, physiology, salt

\begin{abstract}
Perennial ryegrass (Lolium perenne) is a popular cool-season and forage grass around the world. Salinity stress may cause nutrient disorders that influence the growth and physiology of perennial ryegrass. The objective of this study was to identify the genotypic variations in growth traits and nutrient elements in relation to salinity tolerance in perennial ryegrass. Eight accessions of perennial ryegrass [PI265351 (Chile), PI418707 (Romania), PI303012 (UK), PI303033 (The Netherlands), PI545593 (Turkey), PI577264 (UK), PI610927 (Tunisia), and PI632590 (Morocco)] were subjected to 0 (control, no salinity) and $300 \mathrm{~mm} \mathrm{NaCl}$ for $10 \mathrm{~d}$ in a greenhouse. Across accessions, salinity stress decreased plant height (HT), leaf fresh weight (LFW), leaf dry weight (LDW), leaf water concentration (LWC), and concentration of $\mathrm{N}, \mathrm{C}, \mathrm{Ca}^{2+}, \mathrm{Cu}^{2+}, \mathrm{K}^{+}, \mathrm{Mg}^{2+}$, and $\mathrm{K}^{+} / \mathrm{Na}^{+}$ratio and increased $\mathrm{Na}^{+}$concentration. Negative correlations were found between $\mathrm{C}$ and $\mathrm{Na}^{+}$, whereas positive correlations of $\mathrm{K}^{+} / \mathrm{Na}^{+}$with $\mathrm{C}$ and $\mathrm{N}$ were found under salinity treatment. The principal component analysis (PCA) showed that the first, second, and third principal components explained $40.2 \%, 24.9 \%$, and $13.4 \%$ variations of all traits, respectively. Based on loading values from PCA analysis, $\mathrm{LWC}, \mathrm{Na}^{+}$concentration, and $\mathrm{K}^{+} / \mathrm{Na}^{+}$ratio were chosen to evaluate salinity tolerance of accessions, and eight accessions were divided into the tolerant, moderate, and sensitive groups. The tolerant group had relatively higher $\mathrm{LWC}$ and $\mathrm{K}^{+} / \mathrm{Na}^{+}$ratio and concentrations of $\mathrm{C}, \mathrm{P}$, and $\mathrm{Fe}^{2+}$ and lower $\mathrm{Na}^{+}$concentrations than the other two groups, especially the sensitive groups. The result suggested that lower $\mathrm{Na}^{+}$accumulation and higher $\mathrm{K}^{+}$ $/ \mathrm{Na}^{+}$ratio and $\mathrm{LWC}$ were crucial strategies for achieving salinity tolerance of perennial ryegrass.
\end{abstract}

At present, over one-third of cultivated lands are threatened by soil salinization (Rengasamy, 2010). Salinity affects plant growth by imposing both ionic and osmotic stresses. High $\mathrm{Na}^{+}$ concentration disturbs plant ionic homeostasis and the plasmalemma system, decreases plant growth, and even causes plant death (Munns and Tester, 2008). In addition, $\mathrm{Na}^{+}$competes with $\mathrm{K}^{+}$for uptake across the root cell, which caused a decline in the $\mathrm{K}^{+} / \mathrm{Na}^{+}$ratio and nutrient deficiency or ion imbalances (Chen et al., 2015). Salinity-tolerant plants had the capacity to restrict the uptake of $\mathrm{Na}^{+}$, sequester $\mathrm{Na}^{+}$into the vacuoles, and accumulate compatible molecules or compounds, such as proline, glycine betaine, and sugars, to maintain osmotic equilibrium (Thalji and Shalaldeh, 2007).

Nitrogen and $\mathrm{P}$ are the important nutrient elements for plant growth and development (Allen and Bryson, 2007; Sanchez, 2007). Salinity reduced organic matter and nitrogen accumulation in plants (Chen et al., 2015). High salinity prevented plant $\mathrm{N}$ uptake, which limited plant growth (Hu and Schmidhalter,

Received for publication 6 Sept. 2017. Accepted for publication 2 Oct. 2017. This work was supported by the National Natural Science Foundation of China (Grant No. 31730093). Xin Song was supported by the China Scholarship Council.

${ }^{1}$ Corresponding author. E-mail: yjiang@purdue.edu.
1997; Munns and Tester, 2008). Application of N could positively affect plant growth under salinity stress (Rengasamy, 2010). Phosphate availability is reduced in saline soils due to ionic strength effects that reduced the activity of phosphate, and thus salinity decreased the $\mathrm{P}$ concentration in plant tissue (Bloomfield et al., 2014). However, increased P accumulation was also found in the leaf sheath and roots of rice (Oryza sativa) exposed to salinity (Nemati et al., 2011). In addition, $\mathrm{P}$ added to saline soils did not necessarily increase salinity tolerance of some crop species, such as maize (Zea mays), carrot (Daucus carota), sugar beet (Beta vulgaris), and tomato (Solanum lycopersicum) (Champagnol, 1979). The results indicate a complex relationship between salinity and $\mathrm{P}$ nutrition of plants.

It is well-known that salinity stress increases $\mathrm{Na}^{+}$accumulation and decreases $\mathrm{K}^{+}$in plant tissues, including perennial grass species (Hu et al., 2012; Tang et al., 2013a, 2013b). However, shoot concentrations of $\mathrm{Na}^{+}$and $\mathrm{K}^{+}$were not consistently associated with the degree of salinity tolerance (Tang et al., 2013a). High $\mathrm{Na}^{+}$concentration in the soil decreased $\mathrm{Ca}^{2+}$ uptake and transport and inhibited plant growth (Hu and Schmidhalter, 1997). High $\mathrm{Ca}^{2+}$ concentration in plant tissue improved salinity tolerance by excluding $\mathrm{Na}^{+}$(Hawighorst, 2007; Hu and Schmidhalter, 2005). Ashraf and Fatima (1995) found that $\mathrm{CaSO}_{4}$ treatment enhanced the germination of wheat 
(Triticum aestivum) under salinity stress and maintained $\mathrm{K}^{+}$ concentration, suggesting a role of $\mathrm{Ca}^{2+}$ in salinity tolerance. In addition, $\mathrm{Ca}^{2+}$ is strongly competitive with $\mathrm{Mg}^{2+}$ at the binding sites of root plasma membranes, which can interfere with both $\mathrm{Mg}^{2+}$ and $\mathrm{Ca}^{2+}$ uptake under salinity stress (Grattan and Grieve, 1998). The reduced leaf $\mathrm{Ca}^{2+}$ and $\mathrm{Mg}^{2+}$ concentrations were more pronounced with increasing $\mathrm{NaCl}$ concentrations in sour orange (Citrus aurantium) and Carrizo citrange (Citrus sinensis $\times$ Poncirus trifoliata) but such changes in $\mathrm{Ca}^{2+}$ and $\mathrm{Mg}^{2+}$ levels were not consistently shown in Cleopatra mandarin (Citrus reshni) and alemow (Citrus macrophylla) (Ruiz et al., 1997). The results suggest that effects of salinity stress on $\mathrm{Ca}^{2+}$ and $\mathrm{Mg}^{2+}$ concentrations may depend on plant species or cultivars.

Salinity also affects micronutrient uptake in plants. For example, the concentration of $\mathrm{Mn}^{2+}$ increased under salinity stress in barley [Hordeum vulgare (Hassan et al., 1970a)] and rice (Verma and Neue, 1984), but decreased in maize (Hassan et al., 1970b), whereas $\mathrm{Mn}^{2+}, \mathrm{B}$, and $\mathrm{Fe}$ concentrations were unaffected by salinity in young leaves of wheat $(\mathrm{Hu}$ and Schmidhalter, 2001). No clear patterns of changing $\mathrm{Mn}^{2+}$ and $\mathrm{Fe}$ concentrations were observed in four Citrus stocks exposed to increasing $\mathrm{NaCl}$ as mentioned previously (Ruiz et al., 1997). These inconsistent results indicate that nutrient uptake and metabolism are complex and diverse in different plant species under saline environments.

Perennial ryegrass is a popular cool-season perennial grass species (Cornish et al., 1979). It was widely cultivated in temperate climates. Because of wide geographical distribution, significant natural variations of salinity tolerance existed in this species (Tang et al., 2013a, 2013b). However, alterations of nutrient elements to salinity stress are not fully understood in perennial ryegrass. Therefore, the experiment was designed to identify the genotypic variations in growth traits and nutrient elements in relation to salinity tolerance in perennial ryegrass. The results would provide insights into variability of plant

Table 1. Experimental identification (ID) number, accession number (PI), origin, and collection status of perennial ryegrasses used in this experiment about plant growth and nutritional elements in relation to salinity tolerance.

\begin{tabular}{lcll}
\hline ID no. & PI no. & \multicolumn{1}{c}{ Origin } & \multicolumn{1}{c}{ Status } \\
\hline 18 & 265351 & Chile & Uncertain \\
29 & 418707 & Romania & Wild \\
89 & 303012 & UK & Cultivar \\
315 & 303033 & Netherlands & Cultivar \\
451 & 545593 & Turkey & Wild \\
466 & 577264 & UK & Wild \\
556 & 610927 & Tunisia & Wild \\
582 & 632590 & Morocco & Wild \\
\hline
\end{tabular}

growth and nutritional elements of perennial grass species under salinity stress.

\section{Materials and Method}

Plant materials and growth Conditions. Eight accessions of perennial ryegrass [PI265351 (Chile), PI418707 (Romania), PI303012 (UK), PI303033 (The Netherlands), PI545593 (Turkey), PI577264 (UK), PI610927 (Tunisia), and PI632590 (Morocco)] were selected as experimental materials, including five wild, two cultivars, and one uncertain, in accordance with the U.S. Department of Agriculture National Plant Germplasm (USDA-NAGS) classification (Table 1). These accessions have been preserved in greenhouses at Purdue University, West Lafayette, IN through tiller propagation since 2014 and were mature enough for the study. Five to six tillers for each accession were propagated in pots $(10 \mathrm{~cm}$ diameter, $9 \mathrm{~cm}$ deep) containing sand and grown for 10 weeks from 18 Sept. to 30 Nov. 2015 in a greenhouse before exposing to salinity stress. Grasses were cut to 5-6 cm height once per week and irrigated twice per week with a 50-mL half-strength Hoagland solution with $\mathrm{pH}$ of 6.5 , electrical conductivity (EC) of $1.4 \mathrm{dS} \cdot \mathrm{m}^{-1}$ in a greenhouse. The average temperatures in the greenhouse were $\approx 18 \pm 1.0 / 15 \pm 0.5^{\circ} \mathrm{C}$ (day/night), and the average $P A R$ was $\approx 400 \mu \mathrm{mol} \cdot \mathrm{m}^{-2} \cdot \mathrm{s}^{-1}$, with a $10 \mathrm{~h}$ light period of natural and artificial light.

Salinity Treatment. Plants were treated either with halfHoagland solution alone (control) or amended with $300 \mathrm{~mm}$ pure $\mathrm{NaCl}\left(\approx 25.0 \mathrm{dS} \cdot \mathrm{m}^{-1}\right)$. To avoid salinity shock to the grasses, salt concentration was increased gradually by $25 \mathrm{~mm}$ every day until the $100 \mathrm{~mm}$ and then increased with $50 \mathrm{~mm}$ daily from 100 to $300 \mathrm{~mm}$ (total $7 \mathrm{~d}$ after salinity stress initiation). Plants were then cut to 5-6 cm height and exposed to $300 \mathrm{~mm}$ $\mathrm{NaCl}$ for 10 d (21-30 Nov. 2015).

Growth AND ion Measurements. Plant height (HT), LFW, LDW, LWC, and concentrations of N, C, B, $\mathrm{Ca}^{2+}, \mathrm{Cu}^{2+}, \mathrm{Fe}, \mathrm{K}^{+}$, $\mathrm{Mg}^{2+}, \mathrm{Mn}^{2+}, \mathrm{Mo}^{2+}, \mathrm{Na}^{+}$, and $\mathrm{P}$ were measured at the end of salinity treatment.

After reaching $300 \mathrm{~mm} \mathrm{NaCl}$, plants were cut to 5-6 cm and HT1 for each individual pot was recorded. Plants were not cut during the salinity stress treatment. After $10 \mathrm{~d}$ under $300 \mathrm{~mm}$ $\mathrm{NaCl}, \mathrm{HT}$ was measured again (HT2). Plant HT grown during the treatment phase was the difference between HT2 and HT1. All the leaves corresponding to this height in each pot were collected and measured as LFW. The LDW was determined after the leaf tissue was dried at $80^{\circ} \mathrm{C}$ in an oven for $3 \mathrm{~d}$. $\mathrm{LWC}$ was calculated as $[(\mathrm{FW}-\mathrm{DW}) / \mathrm{FW}] \times 100$.

For $\mathrm{B}, \mathrm{Ca}^{2+}, \mathrm{Cu}^{2+}, \mathrm{Fe}, \mathrm{K}^{+}, \mathrm{Mg}^{2+}, \mathrm{Mn}^{2+}, \mathrm{Mo}^{2+}, \mathrm{Na}^{+}$, and $\mathrm{P}$ measurements, we followed the methods described by Tang et al. (2013a). Briefly, $50 \mathrm{mg}$ dry powder of leaves was put into digestion tubes and $5 \mathrm{~mL}$ of $18 \mathrm{M} \mathrm{H}_{2} \mathrm{SO}_{4}$ was added to each tube and mixed on a vortex mixer for $5 \mathrm{~s}$. Then, tubes were

Table 2. Analysis of variance of plant height (HT), leaf fresh weight (LFW), leaf dry weight (LDW), leaf water content (LWC), concentrations of $\mathrm{N}, \mathrm{C}, \mathrm{P}, \mathrm{K}^{+}, \mathrm{Na}^{+}, \mathrm{Ca}^{2+}, \mathrm{Mg}^{2+}, \mathrm{Fe}, \mathrm{B}, \mathrm{Cu}^{2+}, \mathrm{Mn}^{2+}$, and $\mathrm{Mo}^{2+}$ in eight perennial ryegrass accessions under the nonsalinity control and $300 \mathrm{~mm}$ $\mathrm{NaCl}$ treatment.

\begin{tabular}{|c|c|c|c|c|c|c|c|c|c|c|c|c|c|c|c|c|}
\hline & HT & LFW & LDW & LWC & $\mathrm{N}$ & $\mathrm{C}$ & $\mathrm{P}$ & $\mathrm{K}^{+}$ & $\mathrm{Na}^{+}$ & $\mathrm{Ca}^{2+}$ & $\mathrm{Mg}^{2+}$ & $\mathrm{Fe}$ & $\mathrm{B}$ & $\mathrm{Cu}^{2+}$ & $\mathrm{Mn}^{2+}$ & $\mathrm{Mo}^{2+}$ \\
\hline Treatment (T) & $189.8^{* * *}$ & $487.2 * * *$ & $67.2 * * *$ & $67.8^{* *}$ & $597.0 * * *$ & $102.7 * * *$ & ${ }^{N} \mathrm{NS}^{3}$ & $365.8 * * *$ & $649.3 * * *$ & $15.4 * * *$ & $25.1 * *$ & NS 2 & $25.4 * * *$ & $11.4^{*}$ & NS & $51.7 * * *$ \\
\hline Accession (A) & $3.0 *$ & $13.0 * * *$ & $2.9 *$ & $3.1^{*}$ & $7.4 * * *$ & $7.7 * * *$ & NS & $8.2 * * *$ & $5.9 * * *$ & $4.8^{* *}$ & NS & NS & $7.0 * * *$ & NS & $6.6^{* * *}$ & $2.9 *$ \\
\hline $\mathrm{T} \times \mathrm{A}$ & NS & $* * *$ & NS & NS & $*$ & NS & NS & $* * *$ & NS & NS & NS & NS & $* *$ & * & NS & NS \\
\hline
\end{tabular}

*,**,*** indicate significance at $P<0.05, P<0.01$, and $P<0.001$, respectively; ns $=$ not significant. 
placed on the digestion block at $200{ }^{\circ} \mathrm{C}$ for $30 \mathrm{~min}$ and removed from the block and cooled for 10-15 min. After cooling, $5 \mathrm{~mL}$ of $30 \% \mathrm{H}_{2} \mathrm{O}_{2}$ was slowly added to each tube and tubes were vortexed and placed back on the block for $30 \mathrm{~min}$. After all extraction was clear, double deionized water was slowly added to bring the final volume to $50 \mathrm{~mL}$. The final diluted extract was used for determining ion element concentration using a plasma atomic emission spectrometer (ICP 9820; Shimadzu, Columbia, MD). About $30 \mathrm{mg}$ of ground leaf samples were analyzed in a dry combustion analyzer (CHN 2000; Leco Corp., St. Joseph, MI) equipped with IR cell and thermal conductivity detectors

Table 3. Mean values of plant height (HT), leaf fresh weight (LFW), leaf dry weight ( $\mathrm{LDW})$, leaf water content $(\mathrm{LWC})$, concentration of $\mathrm{N}, \mathrm{C}, \mathrm{P}, \mathrm{K}^{+}, \mathrm{Na}^{+}, \mathrm{K}^{+} / \mathrm{Na}^{+}, \mathrm{Ca}^{2+}, \mathrm{Mg}^{2+}, \mathrm{Fe}, \mathrm{B}, \mathrm{Cu}^{2+}, \mathrm{Mn}^{2+}$, and $\mathrm{Mo}^{2+}$ across eight accessions of perennial ryegrass under the nonsalinity control and $300 \mathrm{~mm} \mathrm{NaCl}$ stress.

\begin{tabular}{|c|c|c|c|c|}
\hline \multirow[b]{2}{*}{ Traits } & \multicolumn{2}{|c|}{ Control } & \multicolumn{2}{|c|}{$300 \mathrm{~mm} \mathrm{NaCl}$} \\
\hline & Range & Mean & Range & Mean \\
\hline HT (cm) & $10.4-17.7$ & 13.6 & $4.1-6.1$ & 4.9 \\
\hline LFW (g) & $2.18-4.31$ & 2.9 & $0.74-1.40$ & 1.02 \\
\hline LDW (g) & $0.32-0.56$ & 0.41 & $0.14-0.35$ & 0.26 \\
\hline LWC (\%) & $81.3-87.0$ & 85.4 & $66.4-81.0$ & 75.0 \\
\hline $\mathrm{N}\left(\mathrm{mg} \cdot \mathrm{g}^{-1} \mathrm{DW}\right)$ & $43.5-51.5$ & 4.9 & $30.0-38.9$ & 33.2 \\
\hline $\mathrm{C}\left(\mathrm{mg} \cdot \mathrm{g}^{-1} \mathrm{DW}\right)$ & $391.9-428.7$ & 406.0 & $336.9-389.5$ & 366.8 \\
\hline $\mathrm{P}\left(\mathrm{mg} \cdot \mathrm{g}^{-1} \mathrm{DW}\right)$ & $4.67-7.04$ & 5.7 & $3.9-6.7$ & 5.1 \\
\hline $\mathrm{K}^{+}\left(\mathrm{mg} \cdot \mathrm{g}^{-1} \mathrm{DW}\right)$ & $42.3-71.2$ & 59.3 & $29.5-38.5$ & 34.3 \\
\hline $\mathrm{Na}^{+}\left(\mathrm{mg} \cdot \mathrm{g}^{-1} \mathrm{DW}\right)$ & $0.71-1.84$ & 1.2 & $33.9-68.9$ & 51.1 \\
\hline $\mathrm{K}^{+} / \mathrm{Na}^{+}$(ratio) & $37.7-88.0$ & 54.0 & $0.50-1.09$ & 0.74 \\
\hline $\mathrm{Ca}^{2+}\left(\mathrm{mg} \cdot \mathrm{g}^{-1} \mathrm{DW}\right)$ & $4.4-8.0$ & 5.7 & $3.6-5.9$ & 4.6 \\
\hline $\mathrm{Mg}^{2+}\left(\mathrm{mg} \cdot \mathrm{g}^{-1} \mathrm{DW}\right)$ & $2.4-3.5$ & 2.8 & $1.8-2.7$ & 2.1 \\
\hline $\mathrm{Fe}\left(\mathrm{mg} \cdot \mathrm{g}^{-1} \mathrm{DW}\right)$ & $0.03-0.12$ & 0.05 & $0.03-0.09$ & 0.05 \\
\hline $\mathrm{B}\left(\mathrm{mg} \cdot \mathrm{g}^{-1} \mathrm{DW}\right)$ & $0.006-0.04$ & 0.02 & $0.006-0.07$ & 0.04 \\
\hline $\mathrm{Cu}^{2+}\left(\mathrm{mg} \cdot \mathrm{g}^{-1} \mathrm{DW}\right)$ & $0.009-0.04$ & 0.03 & $0.009-0.04$ & 0.02 \\
\hline $\mathrm{Mn}^{2+}\left(\mathrm{mg} \cdot \mathrm{g}^{-1} \mathrm{DW}\right)$ & $0.06-0.15$ & 0.08 & $0.05-0.14$ & 0.08 \\
\hline $\mathrm{Mo}^{2+}\left(\mathrm{mg} \cdot \mathrm{g}^{-1} \mathrm{DW}\right)$ & $0.003-0.02$ & 0.009 & $0.02-0.04$ & 0.03 \\
\hline
\end{tabular}

for $\mathrm{C}$ and $\mathrm{N}$ concentrations, respectively (Hernandez-Ramirez et al., 2011).

EXPERIMENTAL DESIGN AND DATA ANALYSIS. The experiment was arranged in a split-plot design, with salinity for the main plot and accession for the subplot. Each accession was randomly assigned within each treatment and each treatment was replicated three times (three pots). Analysis of variance was performed with SPSS (version 19.0; IBM Corp., Armonk, $\mathrm{NY}$ ). The data from the salinity treatment were used for PCA. Based on the PCA results, accessions were divided into the tolerant, moderately tolerant, and sensitive group. Group mean for each trait was compared for illustrating the differences in various traits among the tolerant and sensitive materials.

\section{Results and Discussion}

Phenotypic Variations and CoRrelations among traits. Significant treatment effects were observed for all traits except $\mathrm{P}, \mathrm{Fe}$, and $\mathrm{Mn}^{2+}$ (Table 2). Significant accession effects were also shown on all traits except $\mathrm{P}, \mathrm{Mg}^{2+}, \mathrm{Fe}$, and $\mathrm{Cu}^{2+}$ (Table 2). The interactions between accession and treatment were noted for $\mathrm{LFW}$ and concentration of $\mathrm{N}, \mathrm{K}^{+} \mathrm{B}$, and $\mathrm{Cu}^{2+}$ (Table 2).

A wide range in value of each trait was identified under salinity stress across eight accessions of perennial ryegrass (Table 3). Compared with the nonsalinity control, the mean values of HT, LFW, LDW, and LWC decreased $\approx 64 \%, 65.5 \%$, $36.5 \%$, and $12.2 \%$ under salinity stress, respectively (Table 3 ). The mean concentrations of $\mathrm{N}, \mathrm{C}, \mathrm{P}, \mathrm{K}^{+}, \mathrm{Ca}^{2+}$, and $\mathrm{Mg}^{2+}$ ratio also decreased about $32.7 \%, 9.4 \%, 10.5 \%, 42.2 \%, 19.3 \%$, and $25.0 \%$ at $300 \mathrm{~mm} \mathrm{NaCl}$, compared with the control, respectively. However, the mean concentration of $\mathrm{Na}^{+}, \mathrm{B}$, and $\mathrm{Mo}^{2+}$ increased under salinity stress, especially for $\mathrm{Na}^{+}$with a 42-fold increase in the mean concentration. The mean concentration of $\mathrm{Fe}$ and $\mathrm{Mn}^{2+}$ remained unchanged under the control and salinity treatment. Similar results were obtained from different soybean (Glycine max) accessions under salinity stress, whereas the HT, $\mathrm{FW}, \mathrm{DW}, \mathrm{Ca}^{2+}, \mathrm{K}^{+}$, and $\mathrm{Mg}^{2+}$ concentrations significantly

Table 4. Pearson correlation coefficients among plant height (HT), leaf fresh weight (LFW), dry weight (LDW), water content (LWC), concentrations of $\mathrm{N}, \mathrm{C}, \mathrm{P}, \mathrm{K}^{+}, \mathrm{Na}^{+}, \mathrm{K}^{+} / \mathrm{Na}^{+}$ratio, $\mathrm{Ca}^{2+}, \mathrm{Mg}^{2+}, \mathrm{Fe}, \mathrm{B}, \mathrm{Cu}^{2+}, \mathrm{Mn}^{2+}$, and $\mathrm{Mo}^{2+}$ across eight perennial ryegrass accessions under the nonsalinity control (upper diagonal) and $300 \mathrm{~mm} \mathrm{NaCl}$ treatment (lower diagonal).

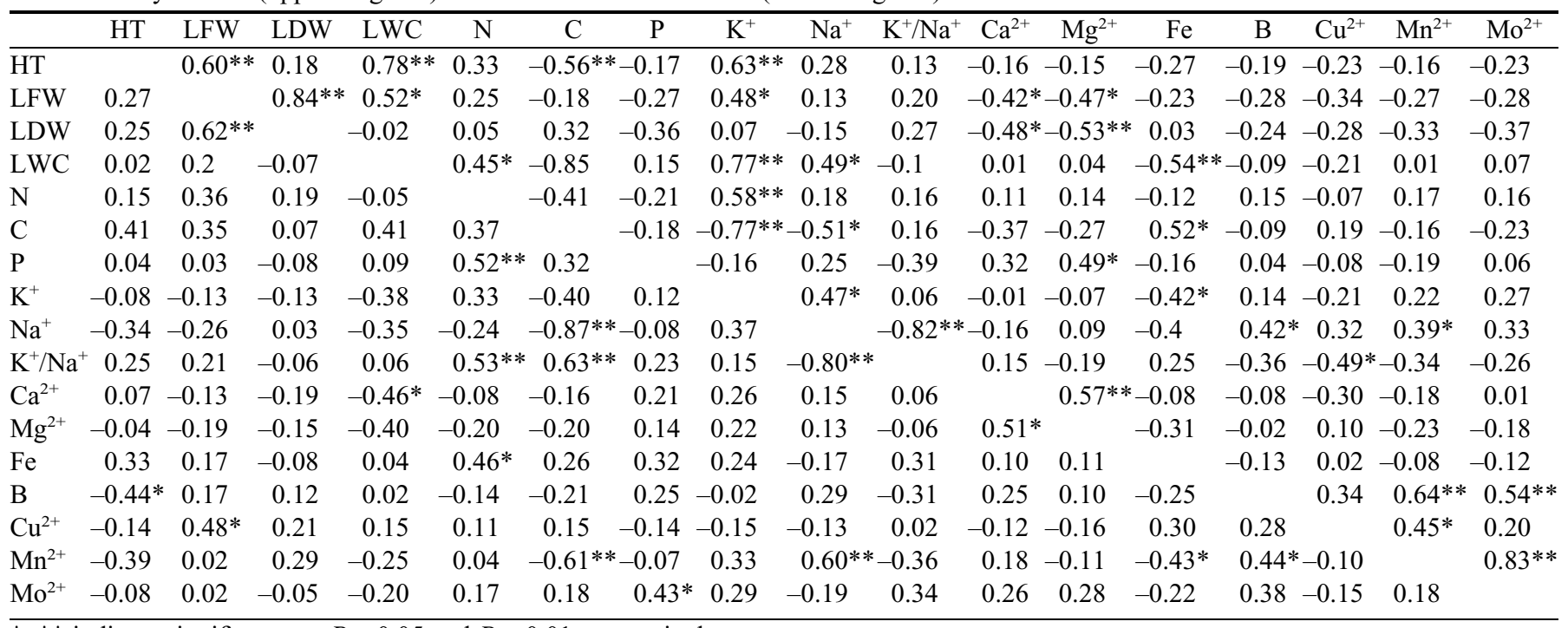

*, ** indicate significance at $P<0.05$ and $P<0.01$, respectively. 
Table 5. Effects of salinity treatment on leaf fresh weight (LFW) and concentrations of $\mathrm{N}, \mathrm{K}^{+}, \mathrm{B}$, and $\mathrm{Cu}^{2+}$ in eight perennial ryegrass accessions by split-plot analysis of variance. ${ }^{\mathrm{z}}$

\begin{tabular}{|c|c|c|c|c|c|c|c|c|c|c|}
\hline \multirow{2}{*}{$\begin{array}{l}\text { ID } \\
\text { no. }\end{array}$} & \multicolumn{2}{|c|}{ LFW (g) } & \multicolumn{2}{|c|}{$\mathrm{N}\left(\mathrm{mg} \cdot \mathrm{g}^{-1} \mathrm{DW}\right)$} & \multicolumn{2}{|c|}{$\mathrm{K}^{+}\left(\mathrm{mg} \cdot \mathrm{g}^{-1} \mathrm{DW}\right)$} & \multicolumn{2}{|c|}{$\mathrm{B}\left(\mathrm{mg} \cdot \mathrm{g}^{-1} \mathrm{DW}\right)$} & \multicolumn{2}{|c|}{$\mathrm{Cu}^{2+}\left(\mathrm{mg} \cdot \mathrm{g}^{-1} \mathrm{DW}\right)$} \\
\hline & Control & Salinity & Control & Salinity & Control & Salinity & Control & Salinity & Control & Salinity \\
\hline 18 & $2.74 \pm 0.4$ & $1.40 \pm 0.1^{*}$ & $49.3 \pm 2.7$ & $35.0 \pm 2.4^{*}$ & $59.3 \pm 4.1$ & $35.1 \pm 2.9^{*}$ & $0.020 \pm 0.01$ & $0.039 \pm 0.01$ & $0.027 \pm 0.01$ & $0.017 \pm 0.002$ \\
\hline 29 & $3.07 \pm 0.4$ & $1.22 \pm 0.1^{*}$ & $50.7 \pm 2.1$ & $38.9 \pm 2.3^{*}$ & $62.1 \pm$ & $35.2 \pm 1.1^{*}$ & $=0.003$ & $0.006 \pm 0.002 *$ & $0.020 \pm 0.01$ & 001 \\
\hline 315 & $2.20 \pm 0.4$ & $0.74 \pm 0.2 *$ & $48.6 \pm 0.5$ & $30.1 \pm 3.0^{*}$ & $55.0 \pm$ & $30.9 \pm 0.5^{*}$ & $0.024 \pm 0.01$ & $0.042 \pm 0.001^{*}$ & $0.037 \pm 0.001$ & $0.015=$ \\
\hline 451 & $3.10 \pm 0.4$ & $0.83 \pm 0.1 *$ & $50.9 \pm 0.4$ & $32.1 \pm 0.8^{*}$ & $71.2 \pm 2.4$ & $37.9 \pm 6.2 *$ & $0.035 \pm 0.01$ & $0.068 \pm 0.02$ & $0.034 \pm 0.01$ & $0.011 \pm 0.004^{*}$ \\
\hline 466 & $2.18 \pm 0.2$ & $0.90 \pm 0.2^{*}$ & $43.5 \pm 2.3$ & $30.0 \pm 1.3^{*}$ & $42.3 \pm 1.3$ & $30.7 \pm 1.2^{*}$ & $0.018 \pm 0.001$ & $0.034 \pm 0.01$ & $0.039 \pm 0.01$ & $0.009 \pm 0.001^{*}$ \\
\hline 582 & $3.08 \pm 0.3$ & $0.77 \pm 0.1 *$ & $51.5 \pm 0.3$ & $32.4 \pm 0.5^{*}$ & $59.3 \pm 4.8$ & $37.0 \pm 4.7^{*}$ & $0.019 \pm 0.003$ & $0.019 \pm 0.01$ & $0.035 \pm 0.004$ & $0.010 \pm 0.002 *$ \\
\hline
\end{tabular}

${ }^{\overline{\mathrm{z}}}$ Comparisons were made between the nonstress control and salinity treatment (300 $\left.\mathrm{mm} \mathrm{NaCl}\right)$ for a given accession and parameter. $*$ indicates significance at $P<0.05$.

${ }^{\mathrm{y}}$ Experimental identification number.

Table 6. Principle component analysis of plant height (HT), leaf fresh weight (LFW), dry weight (LDW), water content (LWC), concentration of $\mathrm{N}, \mathrm{C}, \mathrm{P}, \mathrm{K}^{+}, \mathrm{Na}^{+}, \mathrm{K}^{+} / \mathrm{Na}^{+}$ratio, $\mathrm{Ca}^{2+}, \mathrm{Mg}^{2+}, \mathrm{Fe}, \mathrm{B}$, $\mathrm{Cu}^{2+}, \mathrm{Mn}^{2+}$, and $\mathrm{Mo}^{2+}$ across eight perennial ryegrass accessions under $300 \mathrm{~mm} \mathrm{NaCl}$ stress.

\begin{tabular}{lccc}
\hline Traits & $\mathrm{PC} 1^{\mathrm{z}}$ & $\mathrm{PC} 2$ & $\mathrm{PC} 3$ \\
\hline $\mathrm{HT}$ & -0.548 & 0.465 & 0.239 \\
$\mathrm{FW}$ & 0.429 & 0.753 & -0.082 \\
$\mathrm{DW}$ & -0.332 & 0.626 & -0.354 \\
$\mathrm{LWC}$ & 0.785 & 0.505 & 0.119 \\
$\mathrm{~N}$ & 0.636 & 0.131 & 0.452 \\
$\mathrm{C}$ & 0.735 & 0.183 & -0.432 \\
$\mathrm{P}$ & 0.725 & -0.229 & 0.359 \\
$\mathrm{~K}^{+}$ & 0.295 & -0.485 & 0.722 \\
$\mathrm{Na}^{+}$ & -0.857 & -0.178 & 0.391 \\
$\mathrm{~K}^{+} / \mathrm{Na}^{+}$ratio & 0.955 & -0.059 & -0.103 \\
$\mathrm{Ca}^{2+}$ & -0.166 & -0.913 & -0.284 \\
$\mathrm{Mg}^{2+}$ & 0.454 & -0.740 & -0.263 \\
$\mathrm{Fe}^{\mathrm{B}}$ & 0.670 & -0.012 & 0.209 \\
$\mathrm{Cu}^{2+}$ & -0.675 & -0.012 & 0.105 \\
$\mathrm{Mn}^{2+}$ & -0.116 & 0.817 & -0.133 \\
$\mathrm{Mo}^{2+}$ & -0.282 & 0.130 & 0.739 \\
$\mathrm{PV}^{\mathrm{y}}$ & -0.273 & -0.597 & -0.319 \\
\hline
\end{tabular}

${ }^{\mathrm{z}} \mathrm{PC} 1, \mathrm{PC} 2$, and $\mathrm{PC} 3$ are the first, second, and third principle component, respectively.

${ }^{\mathrm{y}}$ Percentage variation. decreased in the plants (Essa, 2002). In Arabidopsis thaliana, the concentrations of most of the nutrient elements decreased under salinity stress (Hill et al., 2013). Overall, our results supported these observations.

There were 20 positive correlations and 13 negative correlations among growth and nutrient elements under the nonstress control condition, whereas 10 positive correlations and 8 negative correlations were noted under $300 \mathrm{~mm} \mathrm{NaCl}$ (Table 4). Specifically under salinity stress, HT was positively correlated with $\mathrm{FW}$ and $\mathrm{LWC}$, whereas $\mathrm{K}^{+} / \mathrm{Na}^{+}$ratio was positively correlated with $\mathrm{C}$ and $\mathrm{N}$ but negatively correlated with $\mathrm{Na}^{+}$. In addition, $\mathrm{Mn}^{2+}$ was positively correlated with $\mathrm{B}$ and $\mathrm{Na}^{+}$but negatively correlated with C. P was positively correlated with $\mathrm{N}$ and $\mathrm{Mo}^{2+}$. Positive correlations were also observed between $\mathrm{Cu}^{2+}$ and $\mathrm{FW}$, between $\mathrm{Fe}$ and $\mathrm{N}$, and between $\mathrm{Ca}^{2+}$ and $\mathrm{Mg}^{2+}$. In addition, negative correlations were noted between $\mathrm{B}$ and HT, between $\mathrm{Ca}^{2+}$ and LWC, and between $\mathrm{Na}^{+}$and C. Less correlations under salinity stress may suggest that an element balance was partially disturbed because of high $\mathrm{NaCl}$ concentration. The positive and negative correlations of some elements suggested that $\mathrm{C}, \mathrm{P}, \mathrm{N}, \mathrm{Fe}$, and $\mathrm{K}^{+} / \mathrm{Na}^{+}$could positively impact salinity tolerance, whereas $\mathrm{Na}^{+}, \mathrm{B}$, and $\mathrm{Mn}^{+}$might negatively influence salinity tolerance.

INTERACTIVE EFFECTS ON TRAITS. Although declines in $\mathrm{LFW}, \mathrm{N}$, and $\mathrm{K}^{+}$concentrations were found under $300 \mathrm{~mm}$ $\mathrm{NaCl}$ in all eight accessions, the magnitude of declines in these parameters differed in accessions (Table 5). Concentration of B decreased in accession 29
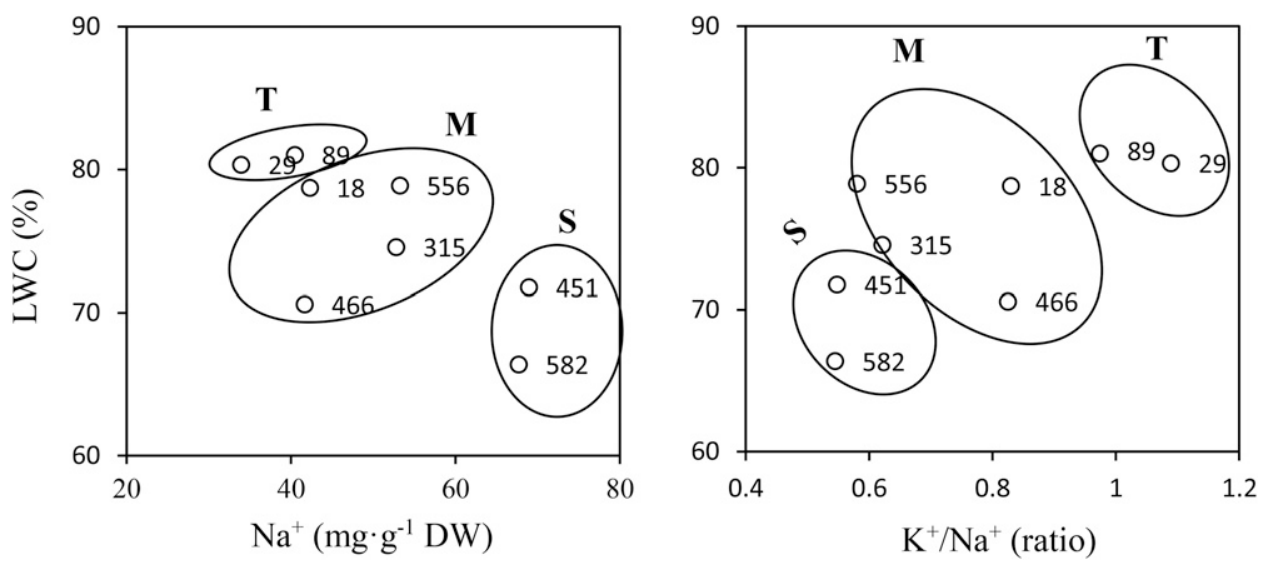

Fig. 1. Separation of perennial ryegrass accessions differing in sensitivities to salinity stress based on leaf water content (LWC) and $\mathrm{Na}^{+}$concentration and $\mathrm{LWC}$ and $\mathrm{K}^{+} / \mathrm{Na}^{+}$ratio under $300 \mathrm{~mm} \mathrm{NaCl}$. Number represents each individual accession. T, M, and S represent the tolerant, moderately tolerant, and sensitive accessions, respectively. but increased in accession 315 and 556 under salinity stress, compared with the control, whereas B concentrations remained unchanged in other accessions (Table 5). Salinity decreased $\mathrm{Cu}^{2+}$ concentration in four accessions but not in other accessions. Nitrogen enables plants to improve growth and yield under salinity stress (Delgado et al., 1994). Salinity reportedly affected the accumulation of ammonium, nitrate, and free amino acids in plants (Amini and Ehsanpour, 2005). The lower reduction in $\mathrm{N}$ concentration could be associated with salinity tolerance. 
PCA ANALYsis. The PCA analysis revealed variations among the traits. The first (PC1), second (PC2), and third principal components (PC3) accounted for $40.2 \%, 24.9 \%$, and $13.4 \%$, respectively. $\mathrm{PC} 1$ showed the larger loading values for the $\mathrm{K}^{+} / \mathrm{Na}^{+}$ ratio (0.955), $\mathrm{Na}^{+}(-0.857)$, and LWC (0.785) (Table 6). PC2 exhibited the larger loading values for LFW $(0.753), \mathrm{Ca}^{2+}$ $(-0.913)$, and $\mathrm{Cu}^{2+}(0.817)$. PC3 had the larger loading values for $\mathrm{Mn}^{2+}(0.739)$ and $\mathrm{K}^{+}(0.722)$ (Table 6). Based on the PC1 results, $\mathrm{LWC}, \mathrm{Na}^{+}$concentration, and $\mathrm{K}^{+} / \mathrm{Na}^{+}$ratio with larger loading values were chosen to evaluate salinity tolerance of accessions (Fig. 1). These parameters are often associated with salinity tolerance (Azadi et al., 2011; Tang et al., 2013b; Thalji and Shalaldeh, 2007). Specifically, accessions 29 and 89 were considered as the salinity tolerant materials $(\mathrm{T})$. The four accessions of $18,315,466$, and 556 were in the moderate-tolerant
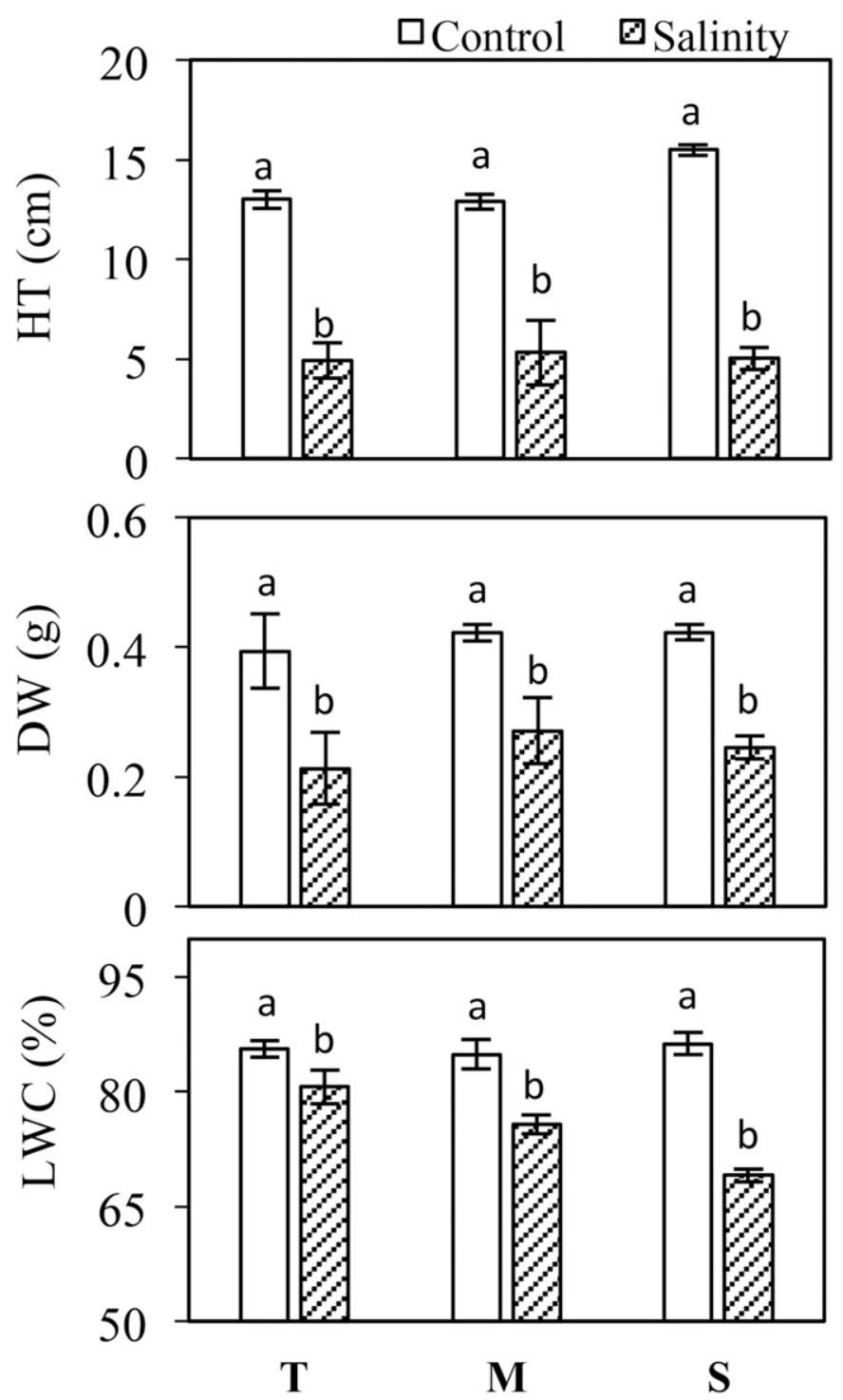

Fig. 2. Plant height (HT), leaf dry weight (LDW), leaf water content (LWC), and carbon concentration of perennial ryegrass as affected by $300 \mathrm{~mm} \mathrm{NaCl}$ in the salinity tolerance group (T), moderately tolerant group (M), and the sensitive group (S) by split-plot analysis of variance. Comparisons are made between the control and salinity treatments. Means followed by the same letter within a group are not significantly different at $P<0.05$. Bars indicate SD. group (M), and accessions 451 and 582 were salinity sensitive accessions (S).

Growth Responses to treatments. Compared with the control, the mean HT was reduced by $62.2 \%, 58.7 \%$, and $67.5 \%$ for the T, M and S groups, respectively (Fig. 2). LWC decreased only $5.7 \%$ for $\mathrm{T}, 10.8 \%$ for $\mathrm{M}$, and $20 \%$ for S. However, the reduction of LDW did not differ in the three groups (Fig. 2). Reduced growth was also observed in other plant species exposed to high salinity stress (Azadi et al., 2011; Brugnoli and Lauteri, 1991; Hu et al., 2012). Our results indicated that lower reductions on LWC could be associated with salinity tolerance in perennial ryegrass.

RESPONSES OF $\mathbf{N A}^{+}$AND $\mathrm{K}^{+} / \mathrm{NA}^{+}$. Under the $300 \mathrm{~mm} \mathrm{NaCl}$ treatment, $\mathrm{Na}^{+}$concentration was $37.2 \mathrm{mg} \cdot \mathrm{g}^{-1} \mathrm{DW}$ in the $\mathrm{T}$ group, which was significantly lower than the $\mathrm{M}\left(47.5 \mathrm{mg} \cdot \mathrm{g}^{-1}\right.$ DW) and $\mathrm{S}\left(68.3 \mathrm{mg} \cdot \mathrm{g}^{-1} \mathrm{DW}\right.$ ) groups (Fig. 3). The $\mathrm{K}^{+} / \mathrm{Na}^{+}$ratio in the $\mathrm{T}$ group was significantly higher than that of the $\mathrm{M}$ and $\mathrm{S}$ groups under salinity stress (Fig. 3).

Cytosolic $\mathrm{K}^{+}$and $\mathrm{Na}^{+}$accumulations are mediated by ion transporters and channels (Zhu, 2003). The salt-tolerant Populus euphratica roots exhibited a higher capacity to extrude $\mathrm{Na}^{+}$ than the salt-sensitive Populus popularis after exposure to salinity stress. As a result, $\mathrm{Na}^{+}$accumulation in $P$. euphratica was lower than $P$. popularis (Sun et al., 2009). Our results supported this observation. The salt-tolerant accessions could limit $\mathrm{Na}^{+}$accumulation and keep $\mathrm{K}^{+}$concentration stability under severe salinity stress. Similar results were also observed in barley and wheat (Azadi et al., 2011; Thalji and Shalaldeh, 2007). The results suggest that maintaining a relative higher $\mathrm{K}^{+}$ concentration, lower $\mathrm{Na}^{+}$accumulation, and higher $\mathrm{K}^{+} / \mathrm{Na}^{+}$ ratio level is a crucial strategy for salinity tolerance in perennial ryegrass (Mäser et al., 2001).

Responses of C, $\mathbf{P}, \mathrm{CA}^{2+}$ AND $\mathrm{MG}^{2+}$ TO TREATMENTS. Under $300 \mathrm{~mm} \mathrm{NaCl}$, the concentration of P increased $17.5 \%$ for the T group but decreased by $19.5 \%$ and $21 \%$ for the $\mathrm{M}$ and $\mathrm{S}$ groups, respectively; compared with the control (Fig. 4). The C concentration was significantly reduced by $5.5 \%, 9.4 \%$, and $13.6 \%$ for the T, M, and S groups, respectively (Fig. 4). The reduction of the $\mathrm{Ca}^{2+}$ and $\mathrm{Mg}^{2+}$ concentrations was $27.9 \%$ and $17.5 \%$ for the T group, $15 \%$ and $23.4 \%$ for the $\mathrm{M}$ group, $17.8 \%$ and $30.3 \%$ for the $\mathrm{S}$ group under $300 \mathrm{~mm} \mathrm{NaCl}$, respectively, compared with the control (Fig. 4).

Plants often accumulate more carbohydrates under salinity stress (Nemati et al., 2011; Tang et al., 2013a). Salinity stress reduced the rate of photosynthesis, and the tolerant species could synthesize and maintain more carbohydrates than the sensitive species (Brugnoli and Lauteri, 1991). In this study, the
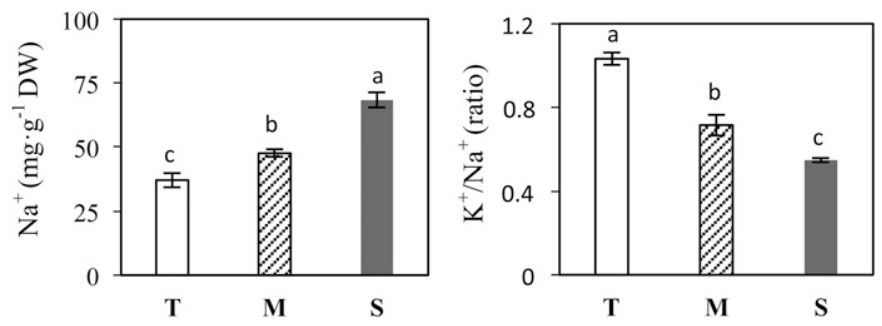

Fig. 3. Concentration of $\mathrm{Na}^{+}$and $\mathrm{K}^{+} / \mathrm{Na}^{+}$ratio of perennial ryegrass as affected by $300 \mathrm{~mm} \mathrm{NaCl}$ treatment in the salinity tolerance group (T), moderately tolerant group (M), and the sensitive group (S) by split-plot analysis of variance. Comparisons are made among the three groups. Means followed by the same letter are not significantly different at $P<0.05$. Bars indicate SD. 

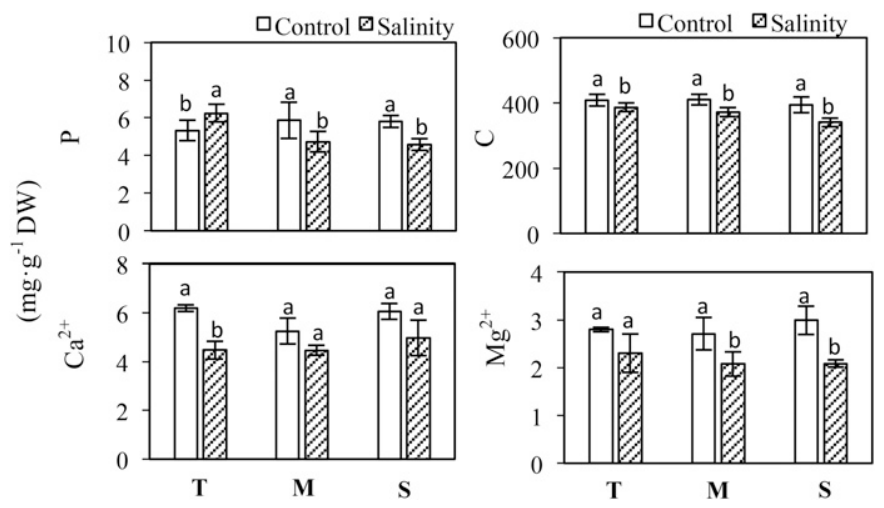

Fig. 4. Concentration of $\mathrm{P}, \mathrm{C}, \mathrm{Ca}^{2+}$, and $\mathrm{Mg}^{2+}$ of perennial ryegrass as affected by $300 \mathrm{~mm} \mathrm{NaCl}$ treatment in the salinity tolerance group $(\mathrm{T})$, moderately tolerant group (M), and the sensitive group (S) by split-plot analysis of variance. Comparisons are made between the control and salinity treatments. Means followed by the same letter within a group are not significantly different at $P<0.05$. Bars indicate SD.

unchanged $\mathrm{C}$ concentration in the tolerant accession demonstrated that salinity tolerance may be associated with higher capacity of maintaining carbon under salinity stress. Salinity decreased $\mathrm{P}$ uptake and the concentration of $\mathrm{P}$ in plant tissue (Grattan and Grieve, 1998; Sharpley et al., 1992) or caused changes in P concentration (Hawighorst, 2007). Our results were partially consistent with previous studies. The $\mathrm{P}$ accumulation in the $\mathrm{M}$ and $\mathrm{S}$ groups decreased under salinity, but the $\mathrm{T}$ group accumulated more P (Fig. 4). The results indicated that the $\mathrm{P}$ level in the plants is vital for salinity tolerance in perennial ryegrass.

Previous studies reported that high $\mathrm{Ca}^{2+}$ concentration could maintain a plant's capacity for nutrient uptake and transport under saline conditions (Fageria et al., 2011). In general, plant $\mathrm{Mg}^{2+}$ uptake is inhibited by high $\mathrm{NaCl}$ stress. However, $\mathrm{Ca}^{2+}$ is strongly competitive with $\mathrm{Mg}^{2+}$ at the binding sites of root plasma membranes, which can interfere with both $\mathrm{Mg}^{2+}$ and $\mathrm{Ca}^{2+}$ uptake under salinity stress. The relatively higher $\mathrm{Mg}^{2+}$ and lower $\mathrm{Ca}^{2+}$ accumulations in the T group and higher $\mathrm{Ca}^{2+}$ over $\mathrm{Mg}^{2+}$ accumulation in the $\mathrm{M}$ and $\mathrm{S}$ groups found in this study suggested that maintenance of a balance between $\mathrm{Mg}^{2+}$ and $\mathrm{Ca}^{2+}$ might be needed for acquiring salinity tolerance in perennial ryegrass accessions.

RESPONSES OF MICRONUTRIENT ELEMENTS TO TREATMENTS. $\mathrm{Mn}^{2+}$ concentration did not differ in all three groups under salinity compared with the control (Fig. 5).

The concentration of $\mathrm{Mo}^{2+}$ increased $250.7 \%$ for the $\mathrm{T}$ group, $208.1 \%$ for the M group, and $145.7 \%$ for the S group exposed to $300 \mathrm{~mm} \mathrm{NaCl}$ compared with the control. Salinity stress dramatically increased Fe concentration to $106.2 \%$ in the $\mathrm{T}$ group and decreased $28.7 \%$ in the $\mathrm{M}$ group and was unaffected in the S group compared with the control (Fig. 5).

Availability of micronutrients to plants may increase, decrease, or remain unchanged under salinity stress (Grattan and Grieve, 1998). In wheat, the leaf B concentration was unaffected by salinity (Bingham et al., 1987). In river red gum (Eucalyptus camaldulensis), salt solution reduced leaf B concentration (Grattan et al., 1997). The increased, decreased, or unchanged B concentration was not consistent with salinity tolerance of perennial ryegrass in this study (Table 5; Fig. 1), suggesting a complex role of B in salinity tolerance. Under $300 \mathrm{~mm} \mathrm{NaCl}$, increased $\mathrm{Fe}$ concentration in the T group and
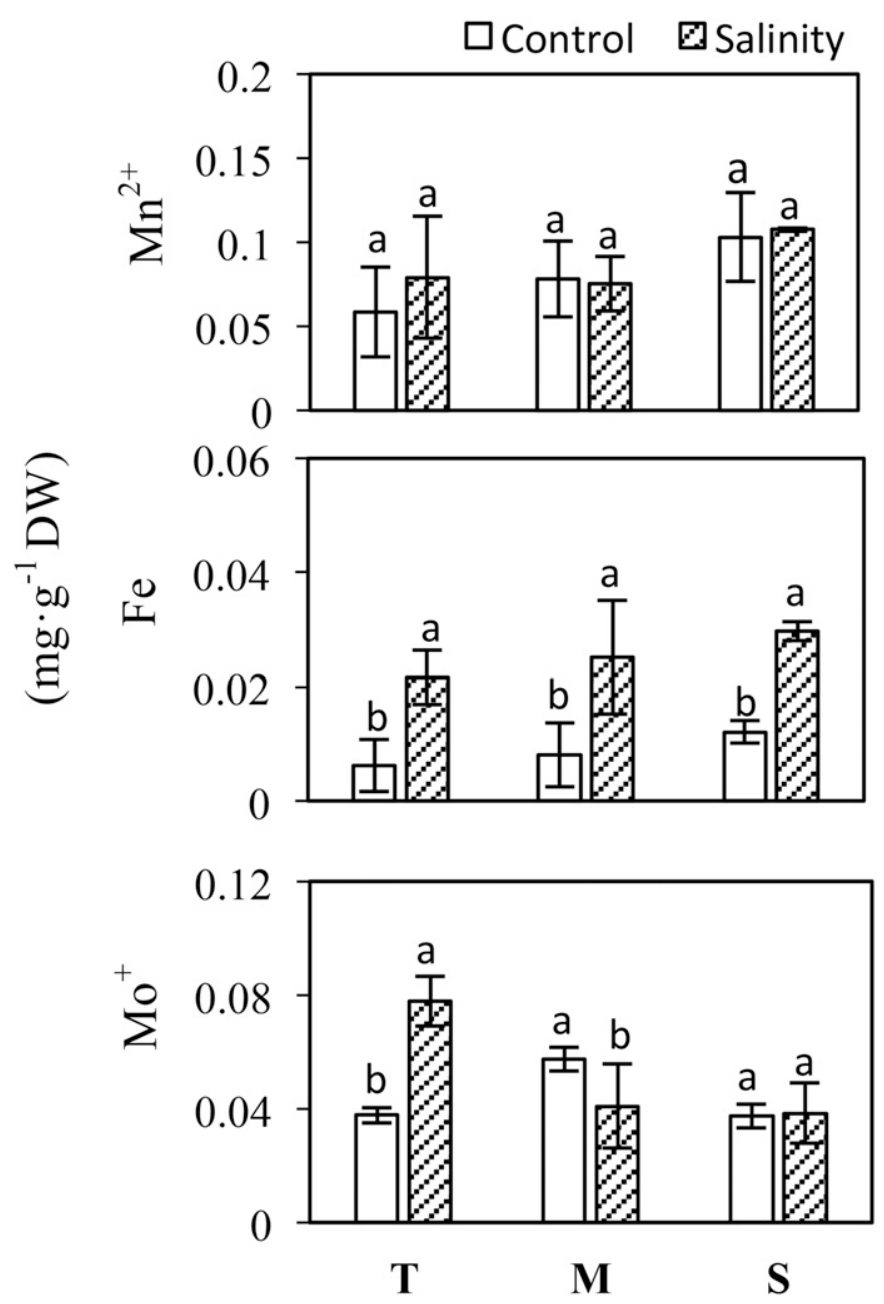

Fig. 5. Concentration of $\mathrm{Fe}, \mathrm{Mn}^{2+}$, and $\mathrm{Mo}^{2+}$ of perennial ryegrass as affected by $300 \mathrm{~mm} \mathrm{NaCl}$ treatment in the salinity tolerance group $(\mathrm{T})$, moderately tolerant group (M), and the sensitive group (S) by split-plot analysis of variance. Comparisons are made between the control and salinity treatments. Means followed by the same letter within a group are not significantly different at $P<0.05$. Bars indicate SD.

decreased or unchanged $\mathrm{Fe}$ concentrations in the $\mathrm{M}$ and $\mathrm{S}$ groups suggested that $\mathrm{Fe}$ could play a role in resisting salinity stress in perennial ryegrass. Similar results were reported for tomato cultivars under salinity stress (Martinez et al., 1987).

Very little attention has been received toward salinity effects on $\mathrm{Cu}^{2+}$ and $\mathrm{Mo}^{2+}$ uptake in plants. In maize, $\mathrm{Cu}^{2+}$ concentration was variable under salinity; however, salinity increased $\mathrm{Mo}^{2+}$ concentration (Rahman et al., 1993). The reduced $\mathrm{Cu}^{2+}$ concentration found in the four accessions with less salinity tolerance demonstrated that higher concentration of $\mathrm{Cu}^{2+}$ could be associated with salinity tolerance. The role of $\mathrm{Mn}^{2+}$ in salinity tolerance is unclear. Salinity reduced $\mathrm{Mn}^{2+}$ uptake in dry bean [Phaseolus vulgaris (Doering et al., 1984)], and additions of $\mathrm{Mn}^{2+}$ to the culture solution increased barley salt tolerance (Cramer and Nowak, 1992). However, $\mathrm{Mn}^{2+}$ was unaffected by salinity stress in peanut [Arachis hypogaea (Chavan and Karadge, 1980)]. The unchanged $\mathrm{Mn}^{2+}$ concentration under salinity in all groups in our study suggested that $\mathrm{Mn}^{2+}$ might not be sensitive to a short period of salinity stress in perennial ryegrass accessions. The role of $\mathrm{Mn}^{2+}$ in salinity 
tolerance needs to be further examined in perennial grass species exposed to a longer period of stress.

\section{Conclusions}

Salinity inhibited growth, reduced concentrations of N, C, $\mathrm{Ca}^{2+}, \mathrm{K}^{+}, \mathrm{Mg}^{2+}, \mathrm{Cu}^{2+}$, and $\mathrm{K}^{+} / \mathrm{Na}^{+}$ratio increased $\mathrm{Na}^{+}$concentration in perennial ryegrass. The tolerant groups had relatively higher LWC and $\mathrm{K}^{+} / \mathrm{Na}^{+}$ratio and concentrations of $\mathrm{C}$, $\mathrm{P}$, and $\mathrm{Fe}^{2+}$ and lower $\mathrm{Na}^{+}$concentrations than the other two groups, especially the sensitive groups. Genotypic variations of growth and nutritional responses of perennial ryegrass to salinity stress provide an important basis for further investigation of molecular mechanisms of salinity tolerance in perennial grass species.

\section{Literature Cited}

Allen, V. and D.J.G.M. Bryson. 2007. Nitrogen, p. 21-50. In: A.V. Barker and D.J. Pilbeam (eds.). Handbook of plant nutrition. CRC Press, Boca Raton, FL.

Amini, F. and A.A. Ehsanpour. 2005. Soluble proteins, proline, carbohydrates and $\mathrm{Na}^{+} / \mathrm{K}^{+}$changes in two tomato (Lycopersicon esculentum Mill.) cultivars under in vitro salt stress. Amer. J. Biochem. Biotechnol. 1:204-208.

Ashraf, M. and H. Fatima. 1995. Responses of salt-tolerant and saltsensitive lines of safflower (Carthamus tinctorius L.) to salt stress. Acta Physiol. Plant. 17:61-70.

Azadi, A., E.M. Hervan, S.A. Mohammadi, F. Moradi, B. Nakhoda, M. Vahabzade, and M. Mardi. 2011. Screening of recombinant inbred lines for salinity tolerance in bread wheat (Triticum aestivum L.). Afr. J. Biotechnol. 10:12875-12881.

Bingham, F., J. Strong, J. Rhoades, and R. Keren. 1987. Effects of salinity and varying boron concentrations on boron uptake and growth of wheat. Plant Soil 97:345-351.

Bloomfield, K.J., G.D. Farquhar, and J. Lloyd. 2014. Photosynthesisnitrogen relationships in tropical forest tree species as affected by soil phosphorus availability: A controlled environment study. Funct. Plant Biol. 41:820-832.

Brugnoli, E. and M. Lauteri. 1991. Effects of salinity on stomatal conductance, photosynthetic capacity, and carbon isotope discrimination of salt-tolerant (Gossypium hirsutum L.) and salt-sensitive (Phaseolus vulgaris L.) C3 non-halophytes. Plant Physiol. 95:628635.

Champagnol, F. 1979. Relationships between phosphate nutrition of plants and salt toxicity. Phosphorus Agr. 76:35-43.

Chavan, P.D. and B. Karadge. 1980. Influence of salinity on mineral nutrition of peanut (Arachis hypogea L.). Plant Soil 54:5-13.

Chen, G., Q. Hu, L. Luo, T. Yang, S. Zhang, Y. Hu, L. Yu, and G. Xu. 2015. Rice potassium transporter OsHAK1 is essential for maintaining potassium mediated growth and functions in salt tolerance over low and high potassium concentration ranges. Plant Cell Environ. 38:2747-2765.

Cornish, M., M. Hayward, and M. Lawrence. 1979. Self-incompatibility in ryegrass. Heredity 43:129-136.

Cramer, G.R. and R.S. Nowak. 1992. Supplemental manganese improves the relative growth, net assimilation and photosynthetic rates of salt stressed barley. Physiol. Plant. 84:600-605.

Delgado, M., F. Ligero, and C. Lluch. 1994. Effects of salt stress on growth and nitrogen fixation by pea, faba-bean, common bean and soybean plants. Soil Biol. Biochem. 26:371-376.

Doering, H.W., G. Schulze, and P. Roscher. 1984. Salinity effects on the micronutrient supply of plants differing in salt resistance. Proc. Intl. Colloq. Opt. Plant Nutr. I:165-172.

Essa, T. 2002. Effect of salinity stress on growth and nutrient composition of three soybean (Glycine max L. Merrill) cultivars. J. Agron. Crop Sci. 188:86-93.
Fageria, N., H. Gheyi, and A. Moreira. 2011. Nutrient bioavailability in salt affected soils. J. Plant Nutr. 34:945-962.

Grattan, S. and C. Grieve. 1998. Salinity-mineral nutrient relations in horticultural crops. Sci. Hort. 78:127-157.

Grattan, S.R., M.C. Shannon, C.M. Grieve, J.A. Poss, D.L. Suarez, and L.E. Francois. 1997. Interactive effects of salinity and boron on the performance and water use of eucalyptus. Acta Hort. 449:607-613.

Hassan, N.A., J.V. Drew, D. Knudsen, and R.A. Olson. 1970a. Influence of soil salinity on production of dry matter and uptake and distribution of nutrients in barley and corn: I. Barley (Hordeum vulgare L.). Agron. J. 62:43-45.

Hassan, N.A., J.V. Drew, D. Knudsen, and R.A. Olson. 1970 b. Influence of soil salinity on production of dry matter and uptake and distribution of nutrients in barley and corn: II. Corn (Zea mays L.). Agron. J. 62:46-48.

Hawighorst, P. 2007. Sodium and calcium uptake, transport and allocation in Populus euphratica and Populus $x$ canescens in response to salinity. PhD Diss., Univ. Göttingen. Göttingen, Germany.

Hernandez-Ramirez, G., S.M. Brouder, D.R. Smith, and G.E. Van Scoyoc. 2011. Nitrogen partitioning and utilization in corn cropping systems: Rotation, N source, and N timing. Eur. J. Agron. 34:190195.

Hill, C.B., D. Jha, A. Bacic, M. Tester, and U. Roessner. 2013. Characterization of ion contents and metabolic responses to salt stress of different Arabidopsis AtHKT1; 1 genotypes and their parental strains. Mol. Plant 6:350-368.

$\mathrm{Hu}, \mathrm{Y}$. and U. Schmidhalter. 1997. Interactive effects of salinity and macronutrient level on wheat. II. Composition. J. Plant Nutr. 20:1169-1182.

$\mathrm{Hu}, \mathrm{Y}$. and U. Schmidhalter. 2001. Effects of salinity and macronutrient levels on micronutrients in wheat. J. Plant Nutr. 24:273-281.

Hu, Y. and U. Schmidhalter. 2005. Drought and salinity: A comparison of their effects on mineral nutrition of plants. J. Plant Nutr. Soil Sci. 168:541-549.

Hu, L., Z. Huang, S. Liu, and J. Fu. 2012. Growth response and gene expression in antioxidant-related enzymes in two bermudagrass genotypes differing in salt tolerance. J. Amer. Soc. Hort. Sci. 137:134-143.

Mäser, P., S. Thomine, J.I. Schroeder, J.M. Ward, K. Hirschi, H. Sze, I.N. Talke, A. Amtmann, F.J. Maathuis, and D. Sanders. 2001. Phylogenetic relationships within cation transporter families of Arabidopsis. Plant Physiol. 126:1646-1667.

Martinez, V., A. Cerda, and F. Fernandez. 1987. Salt tolerance of four tomato hybrids. Plant Soil 97:233-241.

Munns, R. and M. Tester. 2008. Mechanisms of salinity tolerance. Annu. Rev. Plant Biol. 59:651-681.

Nemati, I., F. Moradi, S. Gholizadeh, M. Esmaeili, and M. Bihamta. 2011. The effect of salinity stress on ions and soluble sugars distribution in leaves, leaf sheaths and roots of rice (Oryza sativa L.) seedlings. Plant Soil Environ. 57:26-33.

Rahman, S., G. Vance, and L. Munn. 1993. Salinity induced effects on the nutrient status of soil, corn leaves and kernels 1. Commun. Soil Sci. Plant Anal. 24:2251-2269.

Rengasamy, P. 2010. Soil processes affecting crop production in saltaffected soils. Funct. Plant Biol. 37:613-620.

Ruiz, D., V. Martínez, and A. Cerdá. 1997. Citrus response to salinity: Growth and nutrient uptake. Tree Physiol. 17:141-150.

Sanchez, C.A. 2007. Phosphorus, p. 51-90. In: A.V. Barker and D.J. Pilbeam (eds.). Handbook of plant nutrition. CRC Press, Boca Raton, FL. Sharpley, A., J. Meisinger, J. Power, and D. Suarez. 1992. Root extraction of nutrients associated with long-term soil management, $\mathrm{p}$. 151-217. In: B. Stewart (ed.). Advances in soil science. Springer, New York, NY.

Sun, J., S. Chen, S. Dai, R. Wang, N. Li, X. Shen, X. Zhou, C. Lu, X. Zheng, and Z. Hu. 2009. NaCl-induced alternations of cellular and tissue ion fluxes in roots of salt-resistant and salt-sensitive poplar species. Plant Physiol. 149:1141-1153. 
Tang, J., J.J. Camberato, X. Yu, N. Luo, S. Bian, and Y. Jiang. 2013a. Growth response, carbohydrate and ion accumulation of diverse perennial ryegrass accessions to increasing salinity. Sci. Hort. 154:73-81.

Tang, J., X. Yu, N. Luo, F. Xiao, J.J. Camberato, and Y. Jiang. 2013b. Natural variation of salinity response, population structure and candidate genes associated with salinity tolerance in perennial ryegrass accessions. Plant Cell Environ. 36:2021-2033.
Thalji, T. and G. Shalaldeh. 2007. Screening wheat and barley genotypes for salinity resistance. J. Agron. 6:75-80.

Verma, T. and H. Neue. 1984. Effect of soil salinity level and zinc application on growth, yield, and nutrient composition of rice. Plant Soil 82:3-14.

Zhu, J.-K. 2003. Regulation of ion homeostasis under salt stress. Curr. Opin. Plant Biol. 6:441-445. 